\title{
TSPO Ligands Boost Mitochondrial Function and Pregnenolone Synthesis
}

\author{
Imane Lejri ${ }^{\mathrm{a}, \mathrm{b}, 1}$, Amandine Grimm ${ }^{\mathrm{a}, \mathrm{b}, 1}$, François Halléc ${ }^{\mathrm{c}}$, Mustapha Abarghaz ${ }^{\mathrm{c}}$, Christian Klein ${ }^{\mathrm{d}}$, \\ Michel Maitre $^{\mathrm{d}}$, Martine Schmitt ${ }^{\mathrm{c}}$, Jean-Jacques Bourguignon ${ }^{\mathrm{c}}$, Ayikoe Guy Mensah-Nyagan ${ }^{\mathrm{d}}$, \\ Frederic Bihel ${ }^{\mathrm{c}}$ and Anne Eckert ${ }^{\mathrm{a}, \mathrm{b}, *}$ \\ ${ }^{a}$ University of Basel, Neurobiology Laboratory for Brain Aging and Mental Health, Transfaculty \\ Research Platform, Molecular \& Cognitive Neuroscience, Basel, Switzerland \\ ${ }^{\mathrm{b}}$ Psychiatric University Clinics, Basel, Switzerland \\ ${ }^{\mathrm{c}}$ Laboratoire d'Innovation Thérapeutique, UMR7200, CNRS, Université de Strasbourg, Faculté \\ de pharmacie, Illkirch, France \\ ${ }^{\mathrm{d}}$ Biopathologie de la Myéline, Neuroprotection et Stratégies Thérapeutiques, INSERM U1119, Fédération \\ de Médecine Translationnelle de Strasbourg (FMTS), Université de Strasbourg, Strasbourg, France
}

Handling Associate Editor: Benedict Albensi

Accepted 22 May 2019

\begin{abstract}
Translocator protein $18 \mathrm{kDa}$ (TSPO) is located in the mitochondrial outer membrane and plays an important role in steroidogenesis and cell survival. In the central nervous system (CNS), its expression is upregulated in neuropathologies such as Alzheimer's disease (AD). Previously, we demonstrated that two new TSPO ligands based on an imidazoquinazolinone termed $2 \mathrm{a}$ and $2 \mathrm{~b}$, stimulated pregnenolone synthesis and ATP production in vitro. In the present study, we compared their effects to those of TSPO ligands described in the literature (XBD173, SSR-180,575, and Ro5-4864) by profiling the mitochondrial bioenergetic phenotype before and after treatment and investigating the protective effects of these ligands after oxidative injury in a cellular model of AD overexpressing amyloid- $\beta(\mathrm{A} \beta)$. Of note, ATP levels increased with rising pregnenolone levels suggesting that the energetic performance of mitochondria is linked to an increased production of this neurosteroid via TSPO modulation. Our results further demonstrate that the TSPO ligands $2 \mathrm{a}$ and $2 \mathrm{~b}$ exerted neuroprotective effects by improving mitochondrial respiration, reducing reactive oxygen species and thereby decreasing oxidative stressinduced cell death as well as lowering $A \beta$ levels. The compounds $2 a$ and $2 b$ show similar or even better functional effects than those obtained with the reference TSPO ligands XBD173 and SSR-180.575. These findings indicate that the new TSPO ligands modulate mitochondrial bioenergetic phenotype and protect against oxidative injury probably through the de novo synthesis of neurosteroids, suggesting that these compounds could be potential new therapeutic tools for the treatment of neurodegenerative disease.
\end{abstract}

Keywords: Alzheimer's disease, bioenergetics phenotype, mitochondria, neuroprotection, oxidative stress, pregnenolone, TSPO ligands

\section{INTRODUCTION}

Translocator protein $18 \mathrm{kDa}$ (TSPO) is known to facilitate the transport of cholesterol from cytosol

\footnotetext{
${ }^{1}$ These authors contributed equally to this work.

*Correspondence to: Professor Anne Eckert, PhD, Head, Neurobiology Lab for Brain Aging and Mental Health, Transfaculty Research Platform Molecular \& Cognitive Neuroscience (MCN), University of Basel, Psychiatric University Clinics Basel, Wilhelm Klein-Strasse 27, CH-4002 Basel, Switzerland. Tel.: +41 61325 5487; Fax: +41 61325 5577; E-mail: anne.eckert@upkbs.ch.
}

to the mitochondrial matrix where it is metabolized into pregnenolone by the cytochrome P450scc $[1,2]$. Pregnenolone is the main precursor of the steroid hormones and neurosteroid biosynthesis [3]. TSPO activation can increase steroid synthesis and inhibits apoptosis and inflammation, thereby decreasing cell damage and promoting cell survival [4]. Neuroactive steroids can bind intracellular steroid hormone receptors and act, like traditional steroids, as transcription factors regulating the gene expression. They can also interact with numerous neurotransmitter 
receptors (e.g., glutamate, gamma-aminobutyric acid (GABA), acetylcholine, norepinephrine, dopamine, and 5-hydroxytryptamine) and regulate neuronal activity [5]. Depending on their pre- or post-synaptic action, they can modulate the synaptic plasticity in specific brain areas and modulate learning, memory, emotion, motivation, and cognition processes [5]. Many central nervous system (CNS) diseases present an upregulation of TSPO including Alzheimer's disease (AD) in which positron emission tomography on brains of $\mathrm{AD}$ patients confirmed an increase of TSPO [6]. The most important endogenous ligands of TSPO are cholesterol and porphyrins showing nanomolar and micromolar affinity for TSPO, respectively [7, 8]. Endozepines, other endogenous ligands of TSPO, are a family of neuropeptides which derives from a polypeptide precursor, the diazepam-binding inhibitor (DBI) that allosterically modulates GABAergic transmission in various neurodegenerative diseases [9]. Biologically active peptide fragments of DBI have been shown to stimulate the mitochondrial steroid synthesis [10]. In cerebrospinal fluid of $\mathrm{AD}$ patients, elevated levels of endozepines were measured [11]. Amyloid- $\beta$ $(A \beta)$, a peptide known to have a key pathogenic role in $\mathrm{AD}$, stimulates the synthesis of endozepines by astrocytes [12]. 4'Chlorodiazepam, a TSPO ligand (LTSPO), has been shown to exert neuroprotective effects against $A \beta$ by a mechanism involving the regulation of apoptosis regulator (e.g., Bax) and surviving factor (e.g., surviving) expression [13].

TSPO ligands could also be effective in neuroprotection by modulating endogenous production of neurosteroids in the nervous system $[1,2,14]$. The stimulation of the neurosteroid synthesis may be a beneficial strategy for AD pathology showing a drop of neurosteroid levels such as allopregnanolone levels in the cerebral cortex of the brain from a triple transgenic mouse model of $\mathrm{AD}(3 \times \mathrm{TgAD})$ as well as postmortem in the brains of humans affected with AD $[15,16]$. Thus, neurosteroids can regulate both regeneration and repair mechanisms in the brain and studies showed the ability of allopregnanolone (AP $\alpha$ ) to promote the regenerative processes in both central and peripheral nervous system [16-21].

In the literature, synthetic ligands of TSPO have been developed for three purposes: 1) to improve the understanding of the underlying molecular mechanisms of TSPO; 2) to be used in medical imaging as markers of inflammation; and 3) to discover new ways to treat diseases affecting the CNS [6]. During the last decades, TSPO ligands were found to increase the level of neurosteroids as pregnenolone and allopregnanolone and therefore studied for their neuroprotective and anxiolytic properties [1, 22-25]. TSPO ligands seem to offer alternative therapeutic strategies focused on reducing the accumulation of $A \beta$ as they simultaneously target multiple facets of the neurodegenerative cascade such as neuroinflammation, oxidative stress, mitochondrial dysfunction, and neuronal loss.

Notably, many TSPO ligands were already described in the literature but suffer from a common problem of solubility. In a previous study from our group, several ligands of TSPO based on an imidazo[1,2-c]quinazolinone scaffold were described with nanomolar affinity and a good selectivity against the central benzodiazepine receptor (see compounds structures and results of binding assay in Supplementary Figures 1 and 2) [26]. In particular, the compounds termed $2 \mathrm{a}$ and $2 \mathrm{~b}$ have been shown to ameliorate the adenosine triphosphate (ATP) production and the production of pregnenolone in human neuroblastoma cells expressing the human amyloid- $\beta$ protein precursor $(\mathrm{A} \beta \mathrm{PP})$, a cellular model of AD.

TSPO is located in the outer mitochondrial membrane [27-29] and interacts with ligands to modulate various molecular biological mechanisms such as mitochondrial reactive oxygen species (ROS) generation, mitochondria membrane potential (MMP), and ATP production as well as the modulation of nuclear gene expression via mitochondrial-nuclear signaling [28-32]. Mitochondria are placed at the center of this study to investigate the effect of our TSPO ligands because these paramount organelles are not only the main producers of energy in the cells, but also to main source of ROS and the seat of neurosteroidogenesis with the synthesis of pregnenolone.

Besides, mitochondrial dysfunction plays a crucial role in $\mathrm{AD}$ pathogenesis and may be placed in the center of the degenerative events. Indeed, the "Alzheimer mitochondrial cascade hypothesis" stated by Swerdlow and Khan (2004) postulates that mitochondrial dysfunction is an early event of the disease which may affect $\mathrm{A} \beta \mathrm{PP}$ expression and processing leading to $A \beta$ accumulation [33].

Therefore, based on preliminary findings [26], we aimed to evaluate the effects of the new TSPO ligands compounds $2 \mathrm{a}$ and $2 \mathrm{~b}$ on mitochondrial bioenergetic phenotype, and to test whether they are able to 1) alleviate bioenergetics deficits observed in $A \beta P P / A \beta$ overexpressing neuroblastoma cells (APP cells), by 
activating the metabolic activity and ameliorating the mitochondrial respiration; 2) reduce production of $\mathrm{A} \beta_{40}$; and 3) exert protective effects on the APP cells by ameliorating bioenergetics and reducing oxidative injury under stress condition. The effectiveness of the new TSPO ligands $2 \mathrm{a}$ and $2 \mathrm{~b}$ were compared to TSPO ligands described in the literature: XBD173, SSR-180,575, and Ro5-4864 (see structures in Supplementary Figure 1).

\section{MATERIALS AND METHODS}

\section{Chemicals and reagents}

Dulbecco's-modified Eagle's medium (DMEM), fetal calf serum (FCS), penicillin/streptomycin, dihydrorhodamine 123 (DHR123), 2', 2 $^{\prime}$ dichlorodihydrofluorescein diacetate (H2DCF-DA), adenosine diphosphate (ADP), hydrogen peroxide $\left(\mathrm{H}_{2} \mathrm{O}_{2}\right)$, pyruvate, succinate, and malate were from Sigma-Aldrich (St. Louis, MO, USA). Glutamax and MitoSOX were from Gibco Invitrogen (Waltham, MA, USA). Horse serum (HS) was from Amimed, Bioconcept (Allschwil, Switzerland). Ligand of the receptor TSPO called LTSPO were synthetized as described previously [26] by the laboratory of CNRS, University of Strasbourg, UMR 7200, Faculty of Pharmacology (Strasbourg, France).

\section{Cell culture}

Human SH-SY5Y neuroblastoma and human embryonic kidney cells (HEK293) were grown at $37^{\circ} \mathrm{C}$ in a humidified incubator chamber under an atmosphere of $7.5 \% \mathrm{CO}_{2}$ in DMEM supplemented with $10 \%$ (v/v) heat-inactivated FCS, $2 \mathrm{mM}$ Glutamax, and $1 \%(\mathrm{v} / \mathrm{v})$ penicillin/streptomycin. Cells were passaged 1-2 times per week, and plated for treatment when they reached $80-90 \%$ confluence. SH-SY5Y cells were stably transfected with DNA constructs harboring human wild-type $\mathrm{APP}_{695}$ (APP) or the expression vector pCEP4 (Invitrogen, Saint Aubin, France) alone (control vector, Co) [34]. Transfected APP cells were grown in DMEM standard medium supplemented with $300 \mu \mathrm{g} / \mathrm{ml}$ hygromycin. HEK cells overexpressing Swedish APP (HEK SWE APP) cells were stably transfected with DNA constructs harboring human wild-type $\mathrm{APP}_{695}$ (APP) and were grown in DMEM standard medium supplemented with $300 \mu \mathrm{g} / \mathrm{ml} \mathrm{G} 418$.

\section{Treatment paradigm}

On the basis of our previous study, the concentration of $10 \mathrm{nM}$ of LTSPO was selected and used in all assays. SH-SY5Y cells were treated in DMEM+10\% FCS one day after plating either with DMEM alone (untreated control condition) or with a final concentration of $10 \mathrm{nM}$ of XBD173, SSR180575, Ro5-4864, $2 \mathrm{a}$, and $2 \mathrm{~b}$, made from a stock solution in dimethyl sulfoxide (DMSO), for $24 \mathrm{~h}$ (final concentration of DMSO $<0.002 \%$, no effect of the vehicle solution (DMSO) alone compared to the untreated condition). For the stress experiments, cells were first pre-treated for $24 \mathrm{~h}$ with LTSPOs and then treated for $3 \mathrm{~h}$ with $500 \mu \mathrm{M} \mathrm{H}_{2} \mathrm{O}_{2}$. Then ATP assays, mitochondrial respiration (RCR), ROS detection and MTT assays were performed. Each assay was repeated at least 3 times.

\section{ATP levels}

Total ATP content of SH-SY5Y cells was determined using a bioluminescence assay (ViaLighTM HT, Cambrex Bio Science, Walkersville, MD, USA) according to the instruction of the manufacturer, as previously described $[35,36]$. SH-SY5Y cells were plated in 5 replicates into a white $96-$ well cell culture plate at a density of $2 \times 10^{4}$ cells/well. The bioluminescent method measures the formation of light from ATP and luciferin by luciferase. The emitted light was linearly related to the ATP concentration and was measured using the multilabel plate reader VictorX5 (Perkin Elmer).

\section{Pregnenolone direct ELISA}

The evaluation of the production of pregnenolone was performed with a direct enzyme-linked immunosorbent assay (ELISA) test (DRG diagnostics (C), Germany), an enzyme immunoassay for the quantitative determination of pregnenolone in $\mathrm{Co}$ and APP cells. SH-SY5Y cells were plated in 4-8 replicates into a white 96-well cell culture plate at a density of $2 \times 10^{4}$ cells/ well overnight. Cells were washed with a saline buffer $(140 \mathrm{mM} \mathrm{NaCl}, 5 \mathrm{mM}$ $\mathrm{KCl}, 1,8 \mathrm{mM} \mathrm{CaCl}_{2}, 1 \mathrm{mM} \mathrm{MgSO} 4+7 \mathrm{H}_{2} \mathrm{O}, 10 \mathrm{mM}$ glucose, $10 \mathrm{mM}$ HEPES/NaOH, 0.1\% BSA, pH 7.4) and treated with molecules of references or TSPO ligands $(20 \mu \mathrm{M})$, and incubated for $2 \mathrm{~h}$. In order to measure the production of pregnenolone, the downstream conversion of pregnenolone was blocked by the addition of trilostane $(25 \mu \mathrm{M})$ and abiraterone 
$(0.1 \mu \mathrm{M})$. The cell supernatant was then harvested and the ELISA test was performed according to the manufacture instructions. The plate was read at $450 \mathrm{~nm}$ using the plate reader Cytation 3 (Biotek).

\section{Determination of mitochondrial membrane potential}

The MMP was measured using the fluorescent dye tetramethylrhodamine, methyl ester, and perchlorate (TMRM). SH-SY5Y cells were plated in 8 replicates into a black 96-well cell culture plate at a density of $2 \times 10^{4}$ cells/well. Cells were loaded with the dye at a concentration of $0.4 \mu \mathrm{M}$ for $15 \mathrm{~min}$. After washing twice with HBSS, the fluorescence was detected using the multilabel plate reader VictorX5 (PerkinElmer) at $530 \mathrm{~nm}$ (excitation) $/ 590 \mathrm{~nm}$ (emission). Transmembrane distribution of the dye was dependent on MMP.

\section{Mitochondrial respiration}

The investigation of mitochondrial respiration was performed using the Seahorse Bioscience XF24 Analyzer. XF24 cell culture microplates were coated with $0.1 \%$ gelatine and cells were plated at a density of $2.5 \times 10^{4}$ cells/well in $100 \mu \mathrm{l}$ of treatment medium containing $10 \%$ FCS, $1 \mathrm{~g} / \mathrm{l}$ glucose, and $4 \mathrm{mM}$ pyruvate. After $24 \mathrm{~h}$ of treatment with molecules of references or LTSPO, cells were washed with $1 \mathrm{x}$ prewarmed mitochondrial assay solution (MAS; $70 \mathrm{mM}$ sucrose, $220 \mathrm{mM}$ mannitol, $10 \mathrm{mM} \mathrm{KH_{2 }} \mathrm{PO}, 4.5 \mathrm{mM}$ $\mathrm{MgCl}_{2}, 2 \mathrm{mM}$ HEPES, $1 \mathrm{mM}$ EGTA, and $0.2 \%(\mathrm{w} / \mathrm{v})$ fatty acid-free BSA, $\mathrm{pH} 7.2$ at $\left.37^{\circ} \mathrm{C}\right)$ and $500 \mu \mathrm{l}$ of pre-warmed $\left(37^{\circ} \mathrm{C}\right)$ MAS containing $1 \mathrm{nM}$ XF plasma membrane permeabilizer (PMP, Seahorse Bioscience), $10 \mathrm{mM}$ pyruvate, $10 \mathrm{mM}$ succinate, and $2 \mathrm{mM}$ malate was added to the wells. The PMP was used to permeabilize intact cells in culture, which circumvents the need for isolation of intact mitochondria and allows the investigation of the oxygen consumption rate (OCR) under different respiratory states induced by the sequential injection of: 1) ADP $(4 \mathrm{mM})$ to induce state $3 ; 2)$ oligomycin $(0.5 \mu \mathrm{M})$ to induce state 40 ; Data were extracted from the Seahorse XF24 software and the RCR (state 3/state 4o), which reflects the mitochondrial respiratory capacity, was calculated.

\section{Oxygen consumption rate and extracellular acidification rate}

The Seahorse Bioscience XF24 Analyzer was used to perform a simultaneous real-time measurement of OCR and extracellular acidification rate (ECAR). XF24 cell culture microplates (Seahorse Bioscience) were coated with $0.1 \%$ gelatine and SH-SY5Y cells were plated at a density of $2.5 \times 10^{4}$ cells / well in $100 \mu \mathrm{l}$ of the treatment medium containing $10 \%$ FCS, $1 \mathrm{~g} / \mathrm{l}$ glucose, and $4 \mathrm{mM}$ pyruvate. After $24 \mathrm{~h}$ of treatment with molecules of references or LTSPO treatment, cells were washed with PBS and incubated with $500 \mu \mathrm{l}$ of assay medium (DMEM, without $\mathrm{NaHCO}_{3}$, without phenol red, with $1 \mathrm{~g} / \mathrm{l}$ glucose, $4 \mathrm{mM}$ pyruvate, and $1 \%$ L-glutamine, $\mathrm{pH} 7.4$ ) at $37^{\circ} \mathrm{C}$ in a $\mathrm{CO}_{2}$-free incubator for $1 \mathrm{~h}$. The plate was placed in the XF24 Analyzer and basal OCR and ECAR were recorded during $30 \mathrm{~min}$.

\section{MTT assays}

To assess cell viability, MTT reduction assays were performed according to the manufacturer's protocol (Cell proliferation kit I (MTT), Roche, Germany). Briefly, native and genetically modified SH-SY5Y cells were seeded at $2 \times 10^{4}$ cells / well into 96-well plates and allowed to attach. After $24 \mathrm{~h}$, neuroblastoma cells were incubated under the following conditions:

To evaluate the protective effects of the selected TSPO ligands $2 a$ and $2 b$, cells were pre-treated for $24 \mathrm{~h}$ at a concentration of $10 \mathrm{nM}$ and then incubated for $3 \mathrm{~h}$ with a concentration of $500 \mu \mathrm{M}$ of $\mathrm{H}_{2} \mathrm{O}_{2}$ capable of killing about $70 \%$ of genetically modified SH-SY5Y cells (APP cells). Values were normalized to the control groups treated with $\mathrm{H}_{2} \mathrm{O}_{2}$ alone.

\section{Detection of $A \beta$ levels}

The Human A $\beta 40$ ELISA kit was used for the quantitative determination of human $A \beta_{40}$ in cell culture supernatants. The ELISA was performed in accordance with the A $\beta$-ELISA kit by Invitrogen. The assay principle is that of a monoclonal antibody specific for the $\mathrm{NH}_{2}$-terminus of human $\mathrm{A} \beta$ has been coated onto the wells of the microtiter strips provided. During the first incubation, standards of known human $A \beta_{40}$ content, controls, and unknown samples are pipetted into the wells and co-incubated with a rabbit antibody specific for the $\mathrm{COOH}$-terminus of the 1-40 A $\beta$ sequence. This $\mathrm{COOH}$-terminal sequence is created upon cleavage of the analyzed precursor. After washing, bound rabbit antibody is detected by the addition of a horseradish peroxidase-labeled anti-rabbit antibody. After a second incubation and washing to remove all 
the unbound enzyme, a substrate solution is added, which is acted upon by the bound enzyme to produce color. The intensity of this colored product is directly proportional to the concentration of human $A \beta_{40}$ present in the original specimen.

\section{Reactive oxygen species detection}

Levels of cytosolic ROS, mitochondrial reactive oxygen species, and specific levels of mitochondrial superoxide anion radicals were assessed using the fluorescent dyes $\mathrm{H}_{2}$ DCF-DA, DHR123 and the Red Mitochondrial Superoxide Indicator (MitoSOX), respectively. SH-SY5Y cells were plated in 6 replicates into a black 96 -well cell culture plate at a density of $2 \times 10^{4}$ cells/well. After LTSPO treatment, cells were loaded with $10 \mu \mathrm{M}$ of DCF or DHR for $15 \mathrm{~min}$ or $5 \mu \mathrm{M}$ of MitoSOX for $90 \mathrm{~min}$ at room temperature in the dark on an orbital shaker. After washing twice with HBSS (Sigma), the formation of green fluorescent products, DCF and DHR, generated by the oxidation of H2DCF-DA and DHR123, respectively, were detected using the multilabel plate reader VictorX5 at $485 \mathrm{~nm}$ (excitation)/538 nm (emission). MitoSOX, which is specifically oxidized by mitochondrial superoxide, exhibits a red fluorescence detected at $535 \mathrm{~nm}$ (excitation)/595 $\mathrm{nm}$ (emission). The intensity of fluorescence was proportional to mitochondrial ROS levels, cytosolic ROS level and superoxide anion radicals in mitochondria.

\section{Statistical analysis}

Data are given as the mean $\pm \mathrm{SEM}$, normalized to the untreated control group $(=100 \%)$. Statistical analyses were performed using the Graph Pad Prism software. For statistical comparisons of more than two groups, One-way ANOVA was used, followed by Dunnett's multiple comparison tests versus the control. For statistical comparisons of two groups, Student unpaired t-test was used. The experimental data are evaluated using the GraphPad-Prism program (GraphPad-Prism, San Diego, CA, USA). $p$-values $<0.05$ were considered statistically significant. The goodness of fits was estimated by the $\mathrm{R}$-squared value $(>0.9)$ using Pearson correlation and linear regression analysis.

\section{RESULTS}

\section{TSPO ligands increased bioenergetics}

After a treatment with the TSPO ligands ( $24 \mathrm{~h}$, at 10 $\mathrm{nM})$, a significant increase in pregnenolone (PREG),
ATP, and MMP levels was detected for the ligands in Co cells (2a.: PREG: $+25.7 \%$, ATP: $+23.4 \%$, MMP: $+30 \%$; 2b: PREG: $+24.9 \%$, ATP: $+20.10 \%$, MMP: $+16.3 \%)$ and in APP cells (2a: PREG: $+65.10 \%$, ATP: $+15.5 \%$, MMP: $+29.4 \%$; 2 b: PREG: $+62.8 \%$, ATP: $+16.4 \%$, MMP: $+24.5 \%$ ) when compared to untreated cells (Fig. 1) confirming our preliminary findings [26]. We then next assessed whether the TSPO ligand-induced increase of pregnenolone levels correlated with ATP or MMP levels after treatment (24 h, at $10 \mathrm{nM}$ ) in Co cells (Fig. 1A, C) and APP cells (Fig. 1B, D) [26]. For that purpose, Pearson correlations were performed. XDB173 and SSR-180,575, but not Ro5-4864, had significant effects on ATP, MMP, and pregnenolone levels similar to those of $2 \mathrm{a}$ and $2 \mathrm{~b}$. Notably, significant positive linear correlations were found between ATP and pregnenolone levels in Co cells (Fig. 1A, $p=0.0188, \mathrm{R}=0.8750$ ) and APP cells (Fig. 1B, $p=0.0103, \mathrm{R}=0.9174$ ) after treatment with the TSPO ligands. In addition, MMP and pregnenolone levels significantly correlated in Co cells (Fig. 1 C, $p=0.0155, \mathrm{R}=0.8923$ ) as well as APP cells (Fig. 1D, $p=0.0302, \mathrm{R}=0.8343$ ). These data suggest that the raise in ATP and MMP levels were preferentially linked to an increase of pregnenolone level.

The mitochondrial oxidative phosphorylation (OXPHOS) and the cellular glycolysis are the two main pathways to produce ATP molecules. Therefore, we evaluated the efficiency of XBD173, SSR180,575, Ro5-4864, and the TSPO ligands $2 \mathrm{a}$ and $2 \mathrm{~b}$ at a concentration of $10 \mathrm{nM}$ after a treatment of $24 \mathrm{~h}$ to modulate one or both pathways. OCR is an indicator of basal respiration, and ECAR is an indicator of glycolysis, and both were monitored simultaneously in real-time (Fig. 2). In Co cells, a significant increase of the OCR was observed after a treatment with $2 b$ and 2a ( $+33 \%$ and $+69 \%$ respectively) (Fig. 2A). Only the TSPO ligand $2 \mathrm{~b}$ significantly increased the ECAR $(+70 \%)$ (Fig. 2B). The bioenergetic phenotype of the Co cells (Fig. 2C), representing OCR versus ECAR under different treatment conditions, revealed that the TSPO ligand $2 \mathrm{~b}$ and $2 \mathrm{a}$ were particularly efficient to increase both parameters, switching the Co cells to a metabolically more active state.

We previously showed that APP cells present a decrease of the OCR and the ECAR compared to the Co cells $[36,37]$. The compounds $2 \mathrm{~b}$ and $2 \mathrm{a}$ were able to increase significantly the defective OCR of APP cells $(+25 \%$ and $+36 \%$, respectively) compared to the untreated group (Fig. 2D) whereas the ECAR was significantly ameliorated by XBD173 (+131\%), 

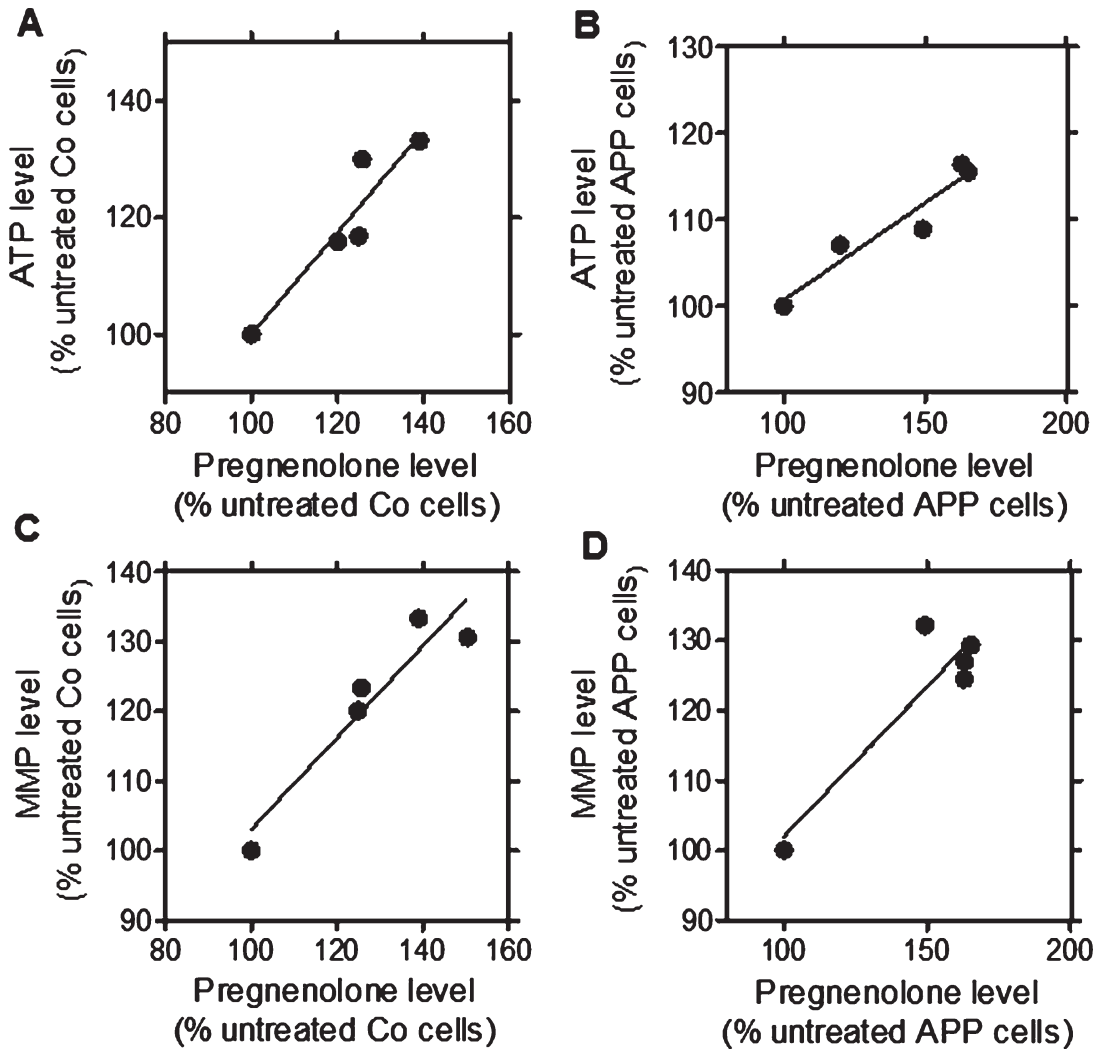

Fig. 1. Significant correlations between ATP and pregnenolone as well as MMP and pregnenolone after treatment with the TSPO ligands $2 \mathrm{a}$ and $2 \mathrm{~b}$ as well as the molecules of reference XBD173 and SSR-180,575 in both cell lines when compared to untreated control cells (Ro5-4864 values were excluded from regression analysis). Graphs represent pregnenolone level in the abscissa versus ATP levels in the ordinate in control (Co) cells (A; confidence: 0.2754 to 1.473; R square: 0.8780; p: 0.0188) and APP cells (B; confidence: 0.1013 to 0.3502; R square: 0.9174; p: 0.0103). Graphs represent pregnenolone level in the abscissa versus MMP levels in the ordinate in control (Co) cells (C; confidence: 0.2376 to 1.075 ; R square: 0.8923; p: 0.0155) and APP cells (D; confidence: 0.07782 to 0.7813; R square: 0.8343; p: 0.0302). Values represent the mean of each treatment group normalized to the untreated control $(=100 \%)$.

SSR-180,575 (+136\%), Ro5-4864 (+103\%), and the TSPO ligand $2 \mathrm{~b}$ and $2 \mathrm{a}(+140 \%$ and $+156 \%$. respectively) (Fig. 2E). The bioenergetic phenotype of the APP cells showed that the compounds $2 b$ and $2 a$ are more efficient than the molecules of references to improve the bioenergetic metabolism (Fig. 2F).

Next, we investigated more deeply the effect of XBD173, SSR-180,575, Ro5-4864, and the TSPO ligand $2 \mathrm{~b}$ and $2 \mathrm{a}$ on mitochondrial respiration by measuring the OCR on permeabilized Co and APP cells after pre-treatment with the Seahorse XF PMP. PBP forms pores in cellular plasma membranes via oligomerization and it targets the cellular plasma membrane selectively, while leaving the mitochondrial membrane intact, thus allowing the control of substrate provision to the mitochondria. APP cells showed lower OCR and RCR compared to Co cells (Fig. 3A, B). We then evaluated the different respiratory states and calculated the RCR (state 3/state 4, Fig. 3 C, D) after treatment TSPO ligands. In Co cells, the RCR was significantly increased after a treatment with XBD173 $(+248 \%), 2 \mathrm{~b}(+230 \%)$, and $2 \mathrm{a}(+103 \%)$ compared to the untreated group (Fig. 3C). In APP cells, 2a significantly increased the basal respiration (state 2, ADP-independent) with an $152 \%$ of increase and $2 b$ with $a+214 \%$ of increase compared to untreated cells (Fig. 3D). Together, in addition to ATP and pregnenolone ameliorating properties, these data demonstrate that our compounds $2 \mathrm{~b}$ and $2 \mathrm{a}$ were also able to improve bioenergetic metabolism and mitochondrial respiration.

\section{TSPO ligands reduced A $\beta$ levels}

Our next step was to examine whether a treatment with TSPO ligands had an effect on the concentration 

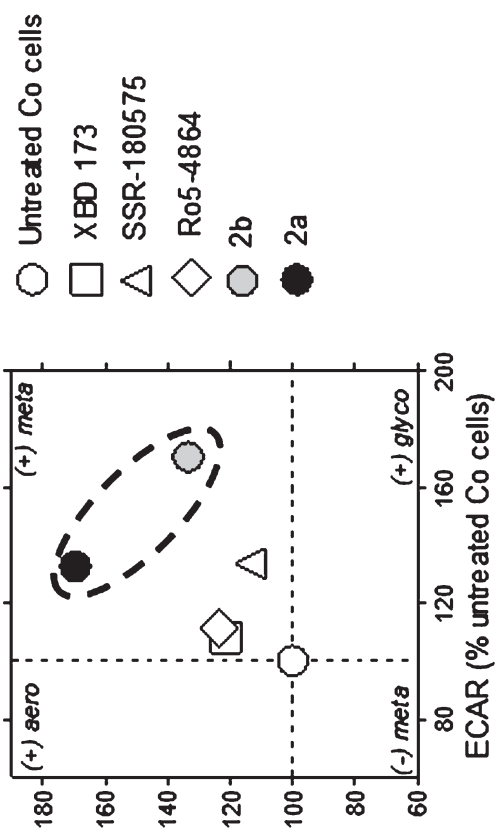

3
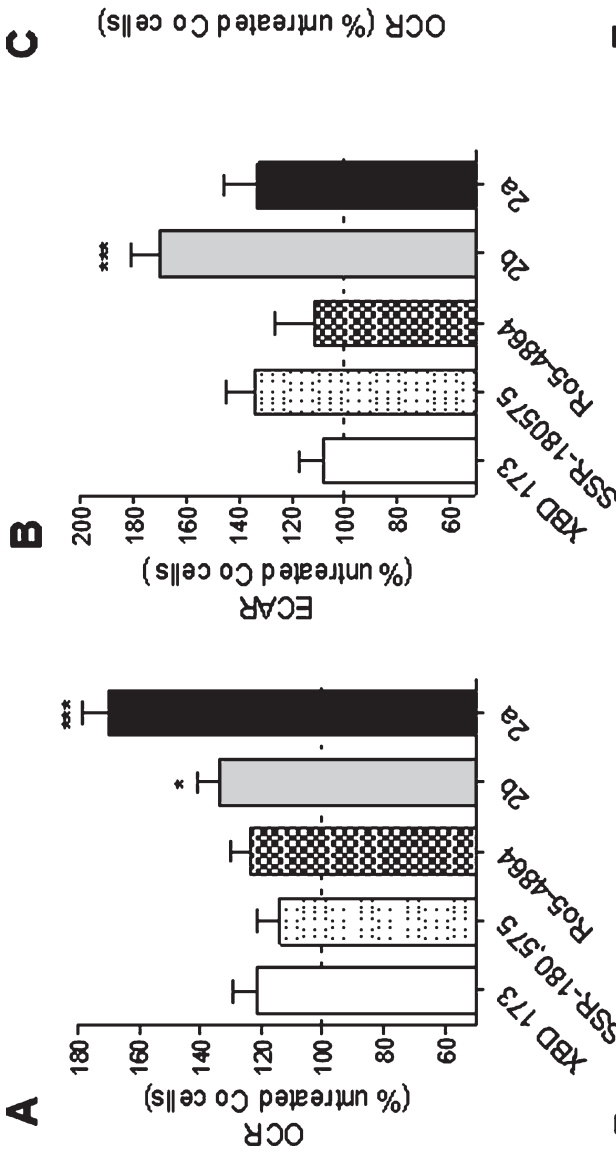
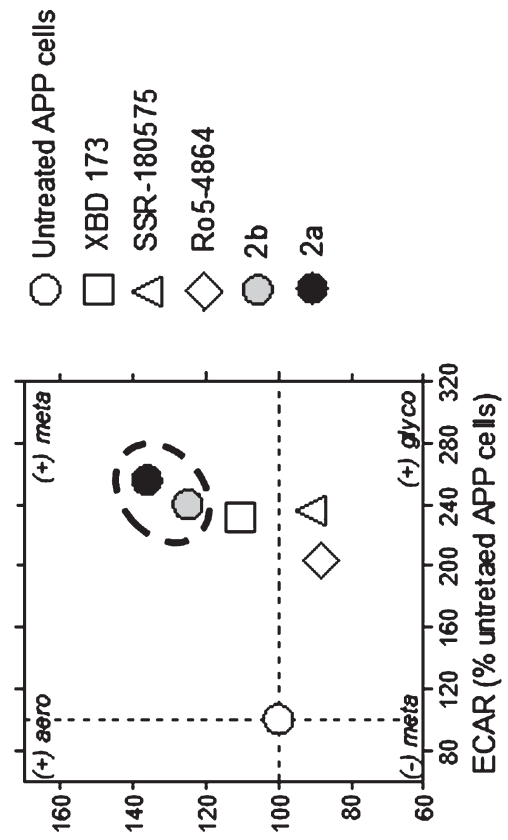

ᄂ (
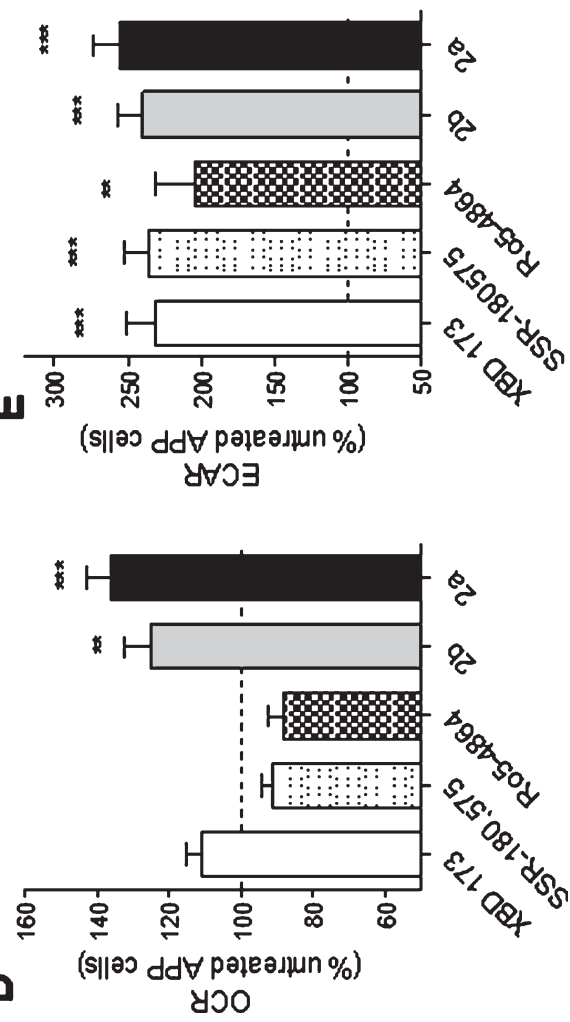

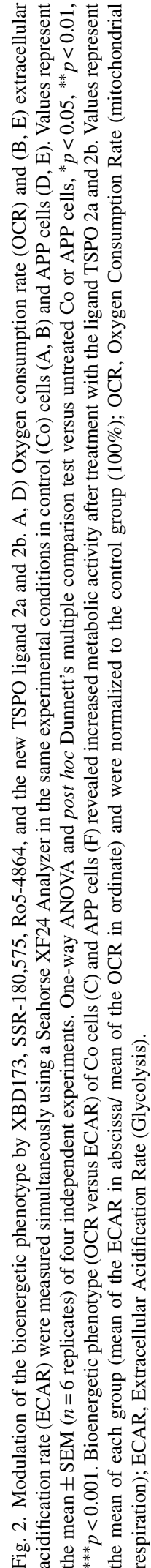



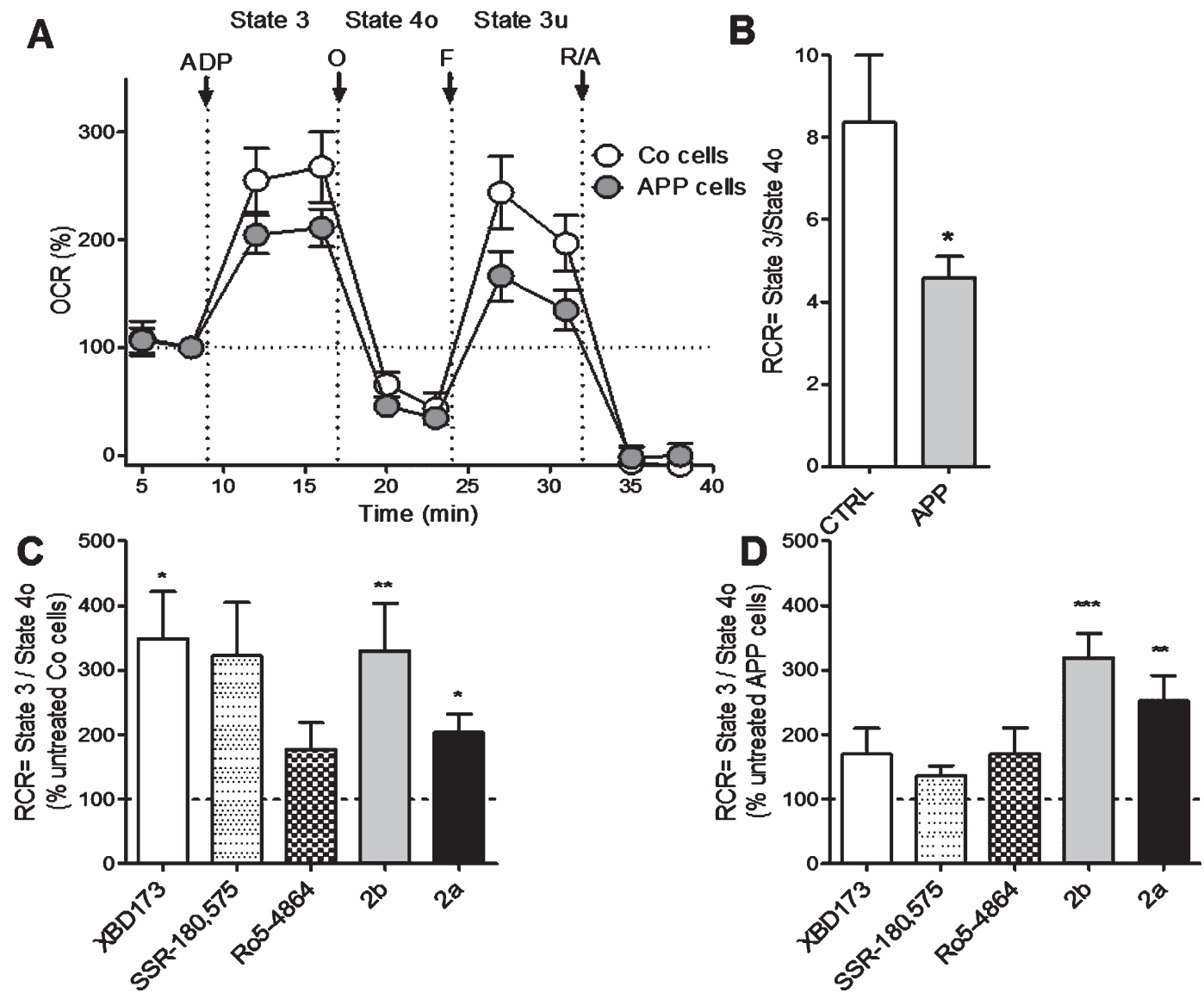

Fig. 3. 2b increases mitochondrial respiratory capacity in control (Co) and APP cells. Oxygen consumption rate (OCR), was measured on permeabilized control Co (C) or APP cells (D) after treatment with LTSPO for $24 \mathrm{~h}$, using a XF24 Analyzer (Seahorse Bioscience). The sequential injection of mitochondrial inhibitors allows the assessment of mitochondrial respiratory state 2, state 3 (ADP-dependent) and state 4o (after oligomycin injection) (see details in the Materials and Methods section). Values corresponding to the different respiratory states (A) are represented as mean $\pm \operatorname{SEM}(n=5$ replicates of three independent experiments/ groups) and were normalized to the state 2 of the untreated group $(=100 \%)$. C, D) The respiratory control ratio $(\mathrm{RCR}=$ state $3 /$ state $4 \mathrm{o}, \mathrm{B})$, which reflects the mitochondrial respiratory capacity, was increased by XBD173, SSR-180,575, 2b, and 2a in Co cells (C) but only 2b improved the RCR in APP cells (D). One-way ANOVA and post hoc Dunnett's multiple comparison test versus untreated Co or APP cells, ${ }^{*} p<0.05,{ }^{* *} p<0.01,{ }^{* * *} p<0.001$.

of $A \beta$ peptide $\left(A \beta_{40}\right)$ in HEK cells overexpressing the Swedish APP mutation (HEK SWE APP) cells. $\mathrm{A} \beta$ levels were determined in the cell supernatant using an ELISA quantification of amyloid 1-40. In HEK SWE APP cells, XBD173, SSR-180,575, 2b, and $2 \mathrm{a}$ were able to decrease significantly amyloid beta 1-40 levels compared to untreated HEK SWE APP cells (Fig. 4).

\section{TSPO ligands decreased oxidative injury}

We investigated the ability of our new TSPO ligands $2 \mathrm{a}$ and $2 \mathrm{~b}$ to protect against $\mathrm{H}_{2} \mathrm{O}_{2}$-evoked bioenergetic abnormalities in this drastic injury condition. Energy loss, cell death, and an increase of cytosolic and mitochondrial ROS as well as the superoxide anion level in Co cells and APP cells were observed after $3 \mathrm{~h}$ of $\mathrm{H}_{2} \mathrm{O}_{2}$ treatment at $500 \mu \mathrm{M}$ (Figs. 5 and 6 ). Of note and as expected, APP cells were stronger affected by the oxidative insult compared to Co cells (Figs. 5 and 6).

In Co cells, the pretreatment with the compounds $2 \mathrm{~b}$ and $2 \mathrm{a}$ ameliorated ATP level $(+24 \%$ and $+19 \%$ respectively, Fig. 6A) compared to the cells only stressed with $500 \mu \mathrm{M}$ of $\mathrm{H}_{2} \mathrm{O}_{2}$. In APP cells, similar effects were observed: $2 b$ and 2a improved ATP levels (up to $20 \%$ of increase) compared to the cells treated only with $500 \mu \mathrm{M}$ of $\mathrm{H}_{2} \mathrm{O}_{2}$ (Fig. 6D). To investigate more deeply the effect of a pre-treatment with the compounds $2 \mathrm{a}$ and $2 \mathrm{~b}$ on mitochondrial respiration, RCR was calculated under oxidative conditions using permeabilized SH-SY5Y (Fig. 6B, E). In Co cells, 


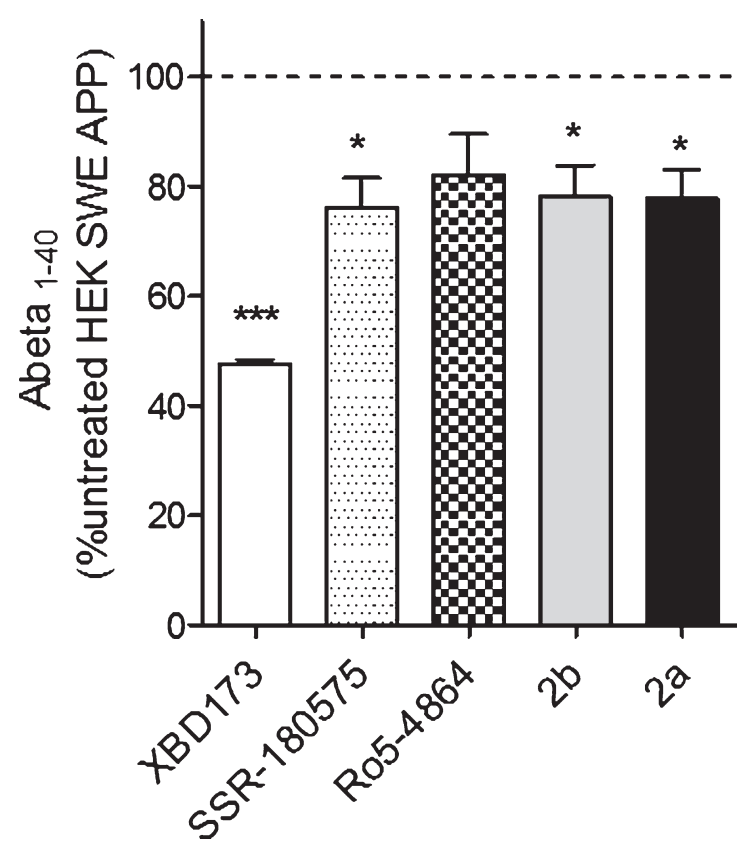

Fig. 4. $A \beta_{1-40}$ levels are significantly reduced after TSPO ligands treatment in the HEK SWE APP cells. ELISA quantification of $A \beta_{1-40}$ in HEK SWE APP cells. Levels of $A \beta_{1-40}$ are significantly reduced after TSPO ligands treatment. One-way ANOVA and post hoc Dunnett's multiple comparison test versus untreated HEK SWE APP cells, ${ }^{*} p<0.05,{ }^{* *} p<0.001$. ELISA, enzymelinked immunosorbent assay; ANOVA, analysis of variance; APP, amyloid precursor protein; SWE, Swedish.

RCR was upregulated after a pre-treatment with the compound $2 \mathrm{~b}$ and $2 \mathrm{a}$ up to $+89 \%$ and up to $175 \%$ of increase in APP cells compared to the cells treated with $500 \mu \mathrm{M}$ of $\mathrm{H}_{2} \mathrm{O}_{2}$ alone (Fig. $6 \mathrm{~B}$, E). Improvement of the cell survival was observed in Co cells after a pre-treatment with the compounds $2 \mathrm{~b}$ and $2 \mathrm{a}$ with respectively $2 \%$ and $4 \%$ of increase to compare to the cells treated with $\mathrm{H}_{2} \mathrm{O}_{2}$ (Fig. $6 \mathrm{C}$ ). In APP cells, only the compound 2 a showed an effect on cell survival $(+10 \%$ of increase) (Fig. 6F).

Finally, concerning the ROS levels, the compounds $2 \mathrm{~b}$ and $2 \mathrm{a}$ reduced cytosolic ROS $(-33 \%$ and $-38 \%$ respectively, Fig. 5), mitochondrial ROS ( $-44 \%$ and $-53 \%$ respectively, Fig. 5) and the superoxide anion level $(-21 \%$ and $-20 \%$, respectively, Fig. 5) in Co cells when compared to cells treated with $500 \mu \mathrm{M}$ of $\mathrm{H}_{2} \mathrm{O}_{2}$ alone. In APP cells, the compounds $2 \mathrm{~b}$ and $2 \mathrm{a}$ reduced the cytosolic ROS $(-31 \%$ and $-28 \%$, respectively, Fig. 5), mitochondrial ROS (-52\% and $-43 \%$, respectively, Fig. 5), and the superoxide anion level $(-33 \%$ and $-35 \%$, respectively, Fig. 5) when compared to cells treated with $500 \mu \mathrm{M}$ of $\mathrm{H}_{2} \mathrm{O}_{2}$ alone.
Together, these data showed that our compounds $2 \mathrm{~b}$ and $2 \mathrm{a}$ were able to protect mitochondria against oxidative injury.

\section{DISCUSSION}

In the present study, we showed that pharmacological treatment with our new TSPO ligands 2a and $2 \mathrm{~b}$ confers protective benefit against $\mathrm{AD}$-induced mitochondrial dysfunctions and oxidative injury by modulating mitochondrial bioenergetic phenotype. Ours findings demonstrate that under physiological condition, the TSPO ligands $2 \mathrm{a}$ and $2 \mathrm{~b}$ were able to 1) alleviate bioenergetic deficits observed in $A P P / A \beta$ overexpressing neuroblastoma cells by activating the metabolic activity, ameliorating the mitochondrial respiration as well as raising the levels of the neurosteroid pregnenolone; 2) reduce the levels of $A \beta_{40}$ in HEK SWE APP cells; and 3 ) under stress condition, our TSPO ligands exerted protective effects on the APP cells by ameliorating bioenergetics and reducing oxidative injury. Thus, the protective pattern of the compounds $2 \mathrm{a}$ and $2 \mathrm{~b}$ are evident under physiological and oxidative stress conditions in a cellular model of AD-related amyloidopathy and with a higher effectiveness compared to TSPO ligands described in the literature (Ro5-4864, XBD173 and SSR-180,575). Indeed, our new compounds were able to increase significantly the OCR in the control and APP cells, as well as the RCR in APP cells when the other compounds showed no significant effects. This indicates a higher efficacy of our new compounds in regulating the oxidative phosphorylation-derived energy production when compared to the TSPO ligands of reference.

Based on our recent work on the discovery of imidazoquinazolinone derivatives as TSPO ligands modulating neurosteroidogenesis and ATP levels in neuroblastoma cells expressing APP [26], we continued to investigate the ability of these new TSPO ligands $2 \mathrm{a}, 2 \mathrm{~b}$ and their molecules of references after $24 \mathrm{~h}$ of treatment $(10 \mathrm{nM})$ to stimulate bioenergetics, and protect $\mathrm{Co}$ and APP cells under stress conditions. $2 \mathrm{a}$ and $2 \mathrm{~b}$ represent a promising chemical family able to bind TSPO in the 2-digit nanomolar range. $2 \mathrm{a}$ and $2 \mathrm{~b}$, as well as the TSPO ligands described in the literature were able to promote ATP production, and pregnenolone biosynthesis in native SH-SY5Y cell and in cells overexpressing APP [26]. In our study, we showed that the increase in ATP levels as well as MMP levels are significantly correlated to 

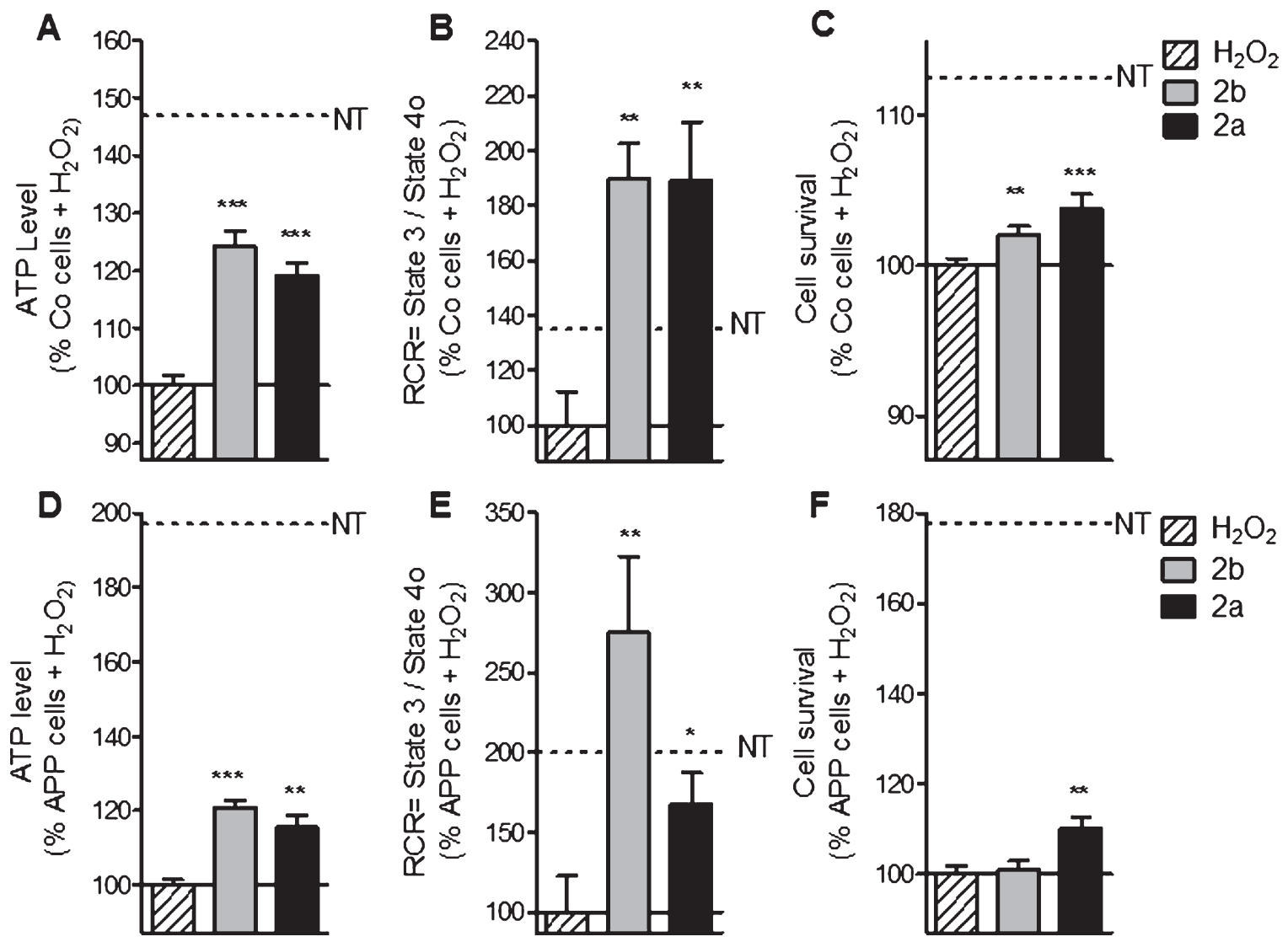

Fig. 5. 2a and $2 \mathrm{~b}$ pre-treatment ameliorate ATP levels, mitochondrial respiration (RCR) and cell survival after oxidative insult in control (Co) and APP cells. Co and APP cells were pre-treated with the TSPO ligand $2 \mathrm{~b}$ or $2 \mathrm{a}$ for $24 \mathrm{~h}$ and then exposed to $\mathrm{H}_{2} \mathrm{O}_{2}(500 \mu \mathrm{M}$ for $3 \mathrm{~h})$. $\mathrm{H}_{2} \mathrm{O}_{2}$ treatment induces a decrease of the ATP level, RCR as well as the cell survival both cell lines. The TSPO ligand $2 \mathrm{~b}$ or $2 \mathrm{a}$ improved the ATP level, RCR and cell survival. Values represent the mean \pm SEM; $n=4-6$ replicates of three independent experiments normalized to Co or APP cells treated with $\mathrm{H}_{2} \mathrm{O}_{2}$. One-way ANOVA and post hoc Dunnett's multiple comparison test versus Co or APP cells treated with $\mathrm{H}_{2} \mathrm{O}_{2},{ }^{*} p<0.05,{ }^{* *} p<0.0001,{ }^{* * *} p<0.001$.

the raise pregnenolone levels suggesting a mechanistic link between bioenergetics and pregnenolone biosynthesis. The increase in ATP levels appeared to be coupled to an increase in MMP as well as improved basal respiration. Our findings showed that only the compounds $2 \mathrm{a}$ and $2 \mathrm{~b}$ significantly ameliorated the metabolic activity by improving respiration as well as glycolysis parameters, and increased the maximum capacity of respiration (RCR) of APP cells compared to the molecules of references. Furthermore, we wanted to know if the ligands $2 \mathrm{a}$ and $2 \mathrm{~b}$ can protect $\mathrm{Co}$ and APP cells against $\mathrm{H}_{2} \mathrm{O}_{2}$-induced oxidative stress. We found that TSPO ligand 2 a protected both cell lines by increasing ATP levels and RCR and reducing ROS. $2 b$ improved the same parameters as the ligand $2 \mathrm{a}$ but is not effective enough to protect against cell death. $2 \mathrm{a}$ and $2 \mathrm{~b}$ as well as XBD173 and SSR-180,575 decreased the levels of $A \beta_{1-40}$. Since it is known that $A \beta_{1-40}$ is able to increase oxidative stress and impair mitochondrial bioenergetics, this mechanism might contribute to the beneficial effect of TSPO ligands described here.

We propose that the neuroprotective effect of our compounds is mediated by their ability to stimulate steroid biosynthesis via TSPO agonism [38]. It is an attractive hypothesis since neurosteroid treatments with progesterone or allopregnanolone have shown beneficial effect in animal models of $\mathrm{AD}$. In our recent study, $2 \mathrm{a}$ and $2 \mathrm{~b}$ have been shown to stimulate the production of the precursor of the neurosteroid biosynthesis, pregnenolone [26].

Our strategy is more based on the neuroprotective effect of TSPO ligands against oxidative injury through the neurosteroidogenesis and the 
A

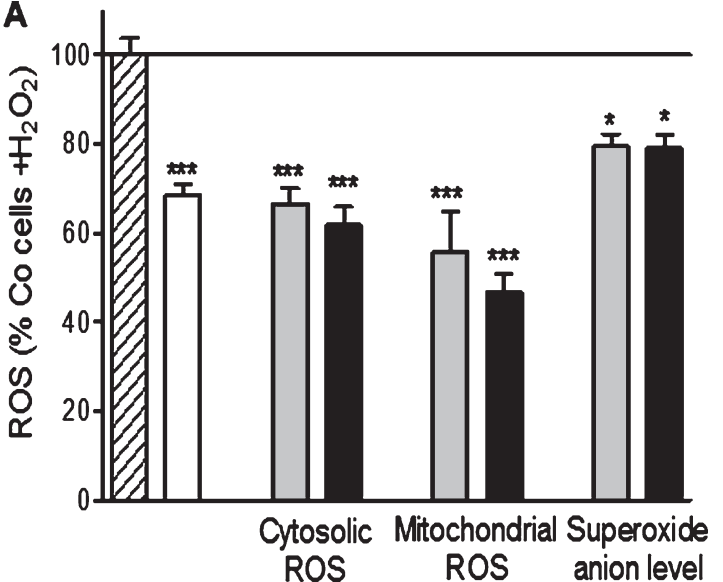

$\square \mathrm{H}_{2} \mathrm{O}_{2}$

No treatment

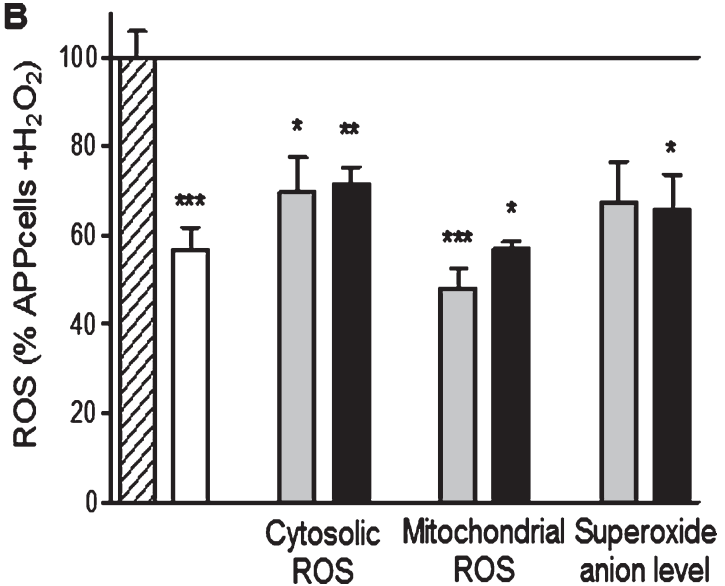

Pretreatment with $2 b+\mathrm{H}_{2} \mathrm{O}_{2}$

Pretreatment with $2 \mathrm{a}+\mathrm{H}_{2} \mathrm{O}_{2}$

Fig. 6. $2 \mathrm{~b}$ and $2 \mathrm{a}$ decreased $\mathrm{H}_{2} \mathrm{O}_{2}$-induced raise of ROS in control (Co, A) and APP (B) cells. Co cells were pre-treated with $10 \mathrm{nM}$ of the TSPO ligand $2 \mathrm{~b}$ or $2 \mathrm{a}$ for $24 \mathrm{~h}$ and then exposed to $\mathrm{H}_{2} \mathrm{O}_{2}(500 \mu \mathrm{M}$ for $3 \mathrm{~h}) . \mathrm{H}_{2} \mathrm{O}_{2}$ treatment induces an increase of the cytoslic ROS, mitochondrial ROS, and superoxide anion level in Co and APP cells. $2 \mathrm{a}$ and $2 \mathrm{~b}$ reduced significantly the ROS generation under oxidative stress conditions. Values represent the mean \pm SEM; $n=4-6$ replicates of three independent experiments normalized to Co or APP cells treated with $\mathrm{H}_{2} \mathrm{O}_{2}$. One-way ANOVA and post hoc Dunnett's multiple comparison test versus Co or APP cells treated with $\mathrm{H}_{2} \mathrm{O}_{2} .{ }^{*} p<0.05$, ${ }^{* *} p<0.0001,{ }^{* * *} p<0.001$.

modulation of the bioenergetic phenotype in a cellular model of $\mathrm{AD}$. In fact, the capacity to boost mitochondrial bioenergetics seems to be a common mechanism of several steroids [35]. Neurosteroids are able to improve cellular bioenergetics by ameliorating mitochondrial respiration and ATP production and regulating redox homeostasis in neuronal cells $[35,36]$. In addition, a treatment with a selection of neurosteroids, namely progesterone, estradiol and testosterone reduced mitochondrial impairments induced by $A \beta$ or abnormal protein tau [36]. TSPO ligands have been shown to promote the biosynthesis of allopregnanolone, a compound currently undergoing clinical trials as a neuroprotector to treat $\mathrm{AD}$, after showing efficacy in mouse models [21]. More recently we showed that allopregnanolone and its analog BR 297 exerted neuroprotective effects to counteract AD-related bioenergetic deficits [37].

Recently, Bader and colleagues demonstrated that pregnenolone biosynthesis is dependent on TSPO expression in mouse BV-2 microglia cells [39]. In fact, they showed that XBD173 and Ro5-4864 were able to stimulate pregnenolone biosynthesis in a TSPO-dependent way and that mitochondrial function is differentially modulated by TSPO ligands [39]. The ligand-specific effects could be in a TSPO-dependent or independent manner on different cellular functions [39]. Further investigations are needed on the effect of our TSPO ligands on TSPO expression providing evidence for both specific TSPO-mediated, as well as off-target effects.

Considering the beneficial effect of TSPO ligands on neuronal viability, regeneration processes, and neuroinflammatory response, one can imagine many therapeutic uses of TSPO ligands in the central and peripheral nervous systems. XBD173 and not etifoxine elevated relevant neurosteroids in the brain at female rats and differed in its ability to exert anti-inflammatory effects. In proteolipid-protein (PLP)-induced experimental autoimmune encephalomyelitis (EAE) SJL/J-mouse model (PLP-EAE mice), XBD173 (10 mg/kg dose) increased allopregnanolone concentrations in spinal and brain tissues and decreased serum level of proinflammatory cytokines [40]. TSPO appears to be implicated in neuroinflammatory processes that also play a role in AD. Therefore, further investigation of pharmacological effects of TSPO ligands are warranted in AD. The effects of benzimidazole derivatives (modulators of mitochondrial activity) were recently tested for their ability to restore cells from $\mathrm{A} \beta$-induced toxicity in vitro in HT22 cells (mouse hippocampal cells) and in vivo as a potential treatment for $\mathrm{AD}$ [41]. Among these compounds, one benzimidazole derivative was able to alleviate $\mathrm{A} \beta$-induced mitochondrial dysfunction in cells by 
recovering the mitochondrial membrane potential, ATP production, cellular viability, and suppressing ROS in vitro as well as to improve cognitive function in animal models of AD. In this study, Kim and collaborators developed novel benzimidazole derivatives as an mPTP blocker to treat mitochondrial dysfunction in $\mathrm{AD}$ [41].

Of note, in the present work, we used neuroblastoma SH-SY5Y cells stably transfected with the human wild-type APP, a cellular model well established which possesses various characteristics found in $\mathrm{AD}$ pathology, including increased $\mathrm{A} \beta$ production, ROS generation, and impaired mitochondrial function (decrease of ATP production, mitochondrial respiration, and mitochondrial complex IV activity) $[36,42,43]$. Interestingly, it has also been demonstrated that APP/A $\beta$-overexpression causes abnormal mitochondrial morphology and distribution in neuroblastoma M17 cells, suggesting the possible occurrence of morphological alterations of mitochondria in APP/A $\beta$ SH-SY5Y cells [44]. Nevertheless, since SH-SY5Y cells are not as highly dependent on the oxidative phosphorylation (OXPHOS) as primary cell cultures to produce ATP, we further need to investigate the mechanism of action of our TSPO ligands in other models, such as primary cell cultures [45].

Taking together, our results convincingly demonstrate that the new imidazoquinazolinone TSPO ligands protect against oxidative stress, induce the de novo synthesis of neurosteroids, improve cellular bioenergetics, and reduce ROS and A $\beta$ levels, suggesting that these compounds could be potential new therapeutic tools for the treatment of $\mathrm{AD}$.

\section{ACKNOWLEDGMENTS}

Parts of this were performed in the frame of a joint $\mathrm{PhD}$ thesis work (IL) co-supervised by AGMN and AE between the University of Strasbourg (France) and the University of Basel (Switzerland) that was part of the collaborative research program of the NeuroRhine Consortium that was funded by INTERREG IV Program (European Fund for Regional Development) in the Upper Rhine Region and the Offensive Science Call 2012. Additional Research Funds were from the Psychiatric University Clinics (UPK research Fonds) and the Swiss National Science Foundation (SNF\#31003A_149728, to AE).

Authors' disclosures available online (https:// www.j-alz.com/manuscript-disclosures/19-0127r1).

\section{SUPPLEMENTARY MATERIAL}

The supplementary material is available in the electronic version of this article: http://dx.doi.org/ 10.3233/JAD-190127.

\section{REFERENCES}

[1] Rupprecht R, Rammes G, Eser D, Baghai TC, Schule C, Nothdurfter C, Troxler T, Gentsch C, Kalkman HO, Chaperon F, Uzunov V, McAllister KH, Bertaina-Anglade V, La Rochelle CD, Tuerck D, Floesser A, Kiese B, Schumacher M, Landgraf R, Holsboer F, Kucher K (2009) Translocator protein $(18 \mathrm{kD})$ as target for anxiolytics without benzodiazepine-like side effects. Science 325, 490-493.

[2] Rupprecht R, Papadopoulos V, Rammes G, Baghai TC, Fan J, Akula N, Groyer G, Adams D, Schumacher M (2010) Translocator protein $(18 \mathrm{kDa})$ (TSPO) as a therapeutic target for neurological and psychiatric disorders. Nat Rev Drug Discov 9, 971-988.

[3] Morrow AL (2007) Recent developments in the significance and therapeutic relevance of neuroactive steroidsIntroduction to the special issue. Pharmacol Ther 116, 1-6.

[4] Repalli J (2014) Translocator protein (TSPO) role in aging and Alzheimer's disease. Curr Aging Sci 7, 168-175.

[5] Zheng P (2009) Neuroactive steroid regulation of neurotransmitter release in the CNS: Action, mechanism and possible significance. Prog Neurobiol 89, 134-152.

[6] Yasuno F, Ota M, Kosaka J, Ito H, Higuchi M, Doronbekov TK, Nozaki S, Fujimura Y, Koeda M, Asada T, Suhara $\mathrm{T}$ (2008) Increased binding of peripheral benzodiazepine receptor in Alzheimer's disease measured by positron emission tomography with [11C]DAA1106. Biol Psychiatry 64, 835-841.

[7] Owen DR, Howell OW, Tang SP, Wells LA, Bennacef I, Bergstrom M, Gunn RN, Rabiner EA, Wilkins MR, Reynolds R, Matthews PM, Parker CA (2010) Two binding sites for [3H]PBR28 in human brain: Implications for TSPO PET imaging of neuroinflammation. J Cereb Blood Flow Metab 30, 1608-1618.

[8] Verma A, Nye JS, Snyder SH (1987) Porphyrins are endogenous ligands for the mitochondrial (peripheral-type) benzodiazepine receptor. Proc Natl Acad Sci U S A 84, 2256-2260.

[9] Mocchetti I, Santi MR (1991) Diazepam binding inhibitor peptide: Cloning and gene expression. Neuropharmacology 30, 1365-1371.

[10] Papadopoulos V, Berkovich A, Krueger KE, Costa E, Guidotti A (1991) Diazepam binding inhibitor and its processing products stimulate mitochondrial steroid biosynthesis via an interaction with mitochondrial benzodiazepine receptors. Endocrinology 129, 1481-1488.

[11] Ferrarese C, Appollonio I, Frigo M, Meregalli S, Piolti R, Tamma F, Frattola L (1990) Cerebrospinal fluid levels of diazepam-binding inhibitor in neurodegenerative disorders with dementia. Neurology 40, 632-635.

[12] Tokay T, Hachem R, Masmoudi-Kouki O, Gandolfo P, Desrues L, Leprince J, Castel H, Diallo M, Amri M, Vaudry H, Tonon MC (2008) Beta-amyloid peptide stimulates endozepine release in cultured rat astrocytes through activation of N-formyl peptide receptors. Glia 56, 13801389. 
[13] Arbo BD, Marques CV, Ruiz-Palmero I, Ortiz-Rodriguez A, Ghorbanpoor S, Arevalo MA, Garcia-Segura LM, Ribeiro MF (2016) 4'-Chlorodiazepam is neuroprotective against amyloid-beta through the modulation of survivin and bax protein expression in vitro. Brain Res 1632, 91-97.

[14] Porcu P, Barron AM, Frye CA, Walf AA, Yang SY, He XY, Morrow AL, Panzica GC, Melcangi RC (2016) Neurosteroidogenesis today: Novel targets for neuroactive steroid synthesis and action and their relevance for translational research. J Neuroendocrinol 28, 12351.

[15] Wang JM, Singh C, Liu L, Irwin RW, Chen S, Chung EJ, Thompson RF, Brinton RD (2010) Allopregnanolone reverses neurogenic and cognitive deficits in mouse model of Alzheimer's disease. Proc Natl Acad Sci U S A 107, 6498-6503.

[16] Naylor JC, Kilts JD, Hulette CM, Steffens DC, Blazer DG, Ervin JF, Strauss JL, Allen TB, Massing MW, Payne VM, Youssef NA, Shampine LJ, Marx CE (2010) Allopregnanolone levels are reduced in temporal cortex in patients with Alzheimer's disease compared to cognitively intact control subjects. Biochim Biophys Acta 1801, 951959.

[17] Wang JM, Johnston PB, Ball BG, Brinton RD (2005) The neurosteroid allopregnanolone promotes proliferation of rodent and human neural progenitor cells and regulates cell-cycle gene and protein expression. J Neurosci $\mathbf{2 5}$, 47064718.

[18] Schumacher M, Hussain R, Gago N, Oudinet JP, Mattern C, Ghoumari AM (2012) Progesterone synthesis in the nervous system: Implications for myelination and myelin repair. Front Neurosci 6, 10.

[19] Sun C, Ou X, Farley JM, Stockmeier C, Bigler S, Brinton RD, Wang JM (2012) Allopregnanolone increases the number of dopaminergic neurons in substantia nigra of a triple transgenic mouse model of Alzheimer's disease. Curr Alzheimer Res 9, 473-480.

[20] Irwin RW, Wang JM, Chen S, Brinton RD (2011) Neuroregenerative mechanisms of allopregnanolone in Alzheimer's disease. Front Endocrinol (Lausanne) 2, 117.

[21] Brinton RD (2013) Neurosteroids as regenerative agents in the brain: Therapeutic implications. Nat Rev Endocrinol 9, 241-250.

[22] Selleri S, Bruni F, Costagli C, Costanzo A, Guerrini G, Ciciani G, Costa B, Martini C (2001) 2-Arylpyrazolo[1,5a]pyrimidin-3-yl acetamides. New potent and selective peripheral benzodiazepine receptor ligands. Bioorg Med Chem 9, 2661-2671.

[23] Ferzaz B, Brault E, Bourliaud G, Robert JP, Poughon G, Claustre Y, Marguet F, Liere P, Schumacher M, Nowicki JP, Fournier J, Marabout B, Sevrin M, George P, Soubrie P, Benavides J, Scatton B (2002) SSR 180575 (7-chloro-N,N,5-trimethyl-4-oxo-3-phenyl-3,5-dihydro4H-pyridazino[4,5-b]indole-1 -acetamide), a peripheral benzodiazepine receptor ligand, promotes neuronal survival and repair. J Pharmacol Exp Ther 301, 1067-1078.

[24] Primofiore G, Da Settimo F, Taliani S, Simorini F, Patrizi MP, Novellino E, Greco G, Abignente E, Costa B, Chelli B, Martini C (2004) N,N-dialkyl-2-phenylindol-3ylglyoxylamides. A new class of potent and selective ligands at the peripheral benzodiazepine receptor. J Med Chem 47, 1852-1855.

[25] Karlstetter M, Nothdurfter C, Aslanidis A, Moeller K, Horn F, Scholz R, Neumann H, Weber BH, Rupprecht R, Langmann T (2014) Translocator protein (18 kDa) (TSPO) is expressed in reactive retinal microglia and modulates microglial inflammation and phagocytosis. J Neuroinflammation 11, 3 .

[26] Hallé F, Lejri I, Abarghaz M, Grimm A, Klein C, Maitre M, Schmitt M, Bourguignon J-J, Mensah-Nyagan AG, Eckert A, Bihel F (2017) Discovery of imidazoquinazolinone derivatives as TSPO ligands modulating neurosteroidogenesis and cellular bioenergetics in neuroblastoma cells expressing amyloid precursor protein. ChemistrySelect 2, 6452-6457.

[27] McEnery MW, Snowman AM, Trifiletti RR, Snyder SH (1992) Isolation of the mitochondrial benzodiazepine receptor: Association with the voltage-dependent anion channel and the adenine nucleotide carrier. Proc Natl Acad Sci U S A 89, 3170-3174.

[28] Caballero B, Veenman L, Gavish M (2013) Role of mitochondrial translocator protein $(18 \mathrm{kDa})$ on mitochondrialrelated cell death processes. Recent Pat Endocr Metab Immune Drug Discov 7, 86-101.

[29] Veenman L, Shandalov Y, Gavish M (2008) VDAC activation by the $18 \mathrm{kDa}$ translocator protein (TSPO), implications for apoptosis. J Bioenerg Biomembr 40, 199-205.

[30] Shargorodsky L, Veenman L, Caballero B, Pe'er Y, Leschiner S, Bode J, Gavish M (2012) The nitric oxide donor sodium nitroprusside requires the $18 \mathrm{kDa}$ Translocator Protein to induce cell death. Apoptosis 17, 647-665.

[31] Veenman L, Alten J, Linnemannstons K, Shandalov Y, Zeno S, Lakomek M, Gavish M, Kugler W (2010) Potential involvement of F0F1-ATP(synth)ase and reactive oxygen species in apoptosis induction by the antineoplastic agent erucylphosphohomocholine in glioblastoma cell lines: A mechanism for induction of apoptosis via the $18 \mathrm{kDa}$ mitochondrial translocator protein. Apoptosis 15, 753-768.

[32] Yasin N, Veenman L, Singh S, Azrad M, Bode J, Vainshtein A, Caballero B, Marek I, Gavish M (2017) Classical and novel TSPO ligands for the mitochondrial TSPO can modulate nuclear gene expression: Implications for mitochondrial retrograde signaling. Int J Mol Sci 18, E786.

[33] Swerdlow RH, Khan SM (2004) A "mitochondrial cascade hypothesis" for sporadic Alzheimer's disease. Med Hypotheses 63, 8-20.

[34] Scheuermann S, Hambsch B, Hesse L, Stumm J, Schmidt C, Beher D, Bayer TA, Beyreuther K, Multhaup G (2001) Homodimerization of amyloid precursor protein and its implication in the amyloidogenic pathway of Alzheimer's disease. J Biol Chem 276, 33923-33929.

[35] Grimm A, Schmitt K, Lang UE, Mensah-Nyagan AG, Eckert A (2014) Improvement of neuronal bioenergetics by neurosteroids: Implications for age-related neurodegenerative disorders. Biochim Biophys Acta 1842, 2427-2438.

[36] Grimm A, Biliouris EE, Lang UE, Götz J, Mensah-Nyagan AG, Eckert A (2016) Sex hormone-related neurosteroids differentially rescue bioenergetic deficits induced by amyloid-beta or hyperphosphorylated tau protein. Cell Mol Life Sci 73, 201-215.

[37] Lejri I, Grimm A, Miesch M, Geoffroy P, Eckert A, MensahNyagan AG (2017) Allopregnanolone and its analog BR 297 rescue neuronal cells from oxidative stress-induced death through bioenergetic improvement. Biochim Biophys Acta 1863, 631-642.

[38] Girard C, Liu S, Cadepond F, Adams D, Lacroix C, Verleye M, Gillardin JM, Baulieu EE, Schumacher M, Schweizer-Groyer G (2008) Etifoxine improves peripheral nerve regeneration and functional recovery. Proc Natl Acad Sci U S A 105, 20505-20510. 
[39] Bader S, Wolf L, Milenkovic VM, Gruber M, Nothdurfter C, Rupprecht R, Wetzel CH (2019) Differential effects of TSPO ligands on mitochondrial function in mouse microglia cells. Psychoneuroendocrinology 106, 65-76.

[40] Leva G, Klein C, Benyounes J, Halle F, Bihel F, Collongues N, De Seze J, Mensah-Nyagan AG, Patte-Mensah C (2017) The translocator protein ligand XBD173 improves clinical symptoms and neuropathological markers in the SJL/J mouse model of multiple sclerosis. Biochim Biophys Acta 1863, 3016-3027.

[41] Kim T, Yang HY, Park BG, Jung SY, Park JH, Park KD, Min SJ, Tae J, Yang H, Cho S, Cho SJ, Song H, Mook-Jung I, Lee J, Pae AN (2017) Discovery of benzimidazole derivatives as modulators of mitochondrial function: A potential treatment for Alzheimer's disease. Eur J Med Chem 125, 1172-1192.

[42] Rhein V, Giese M, Baysang G, Meier F, Rao S, Schulz KL, Hamburger M, Eckert A (2010) Ginkgo biloba extract ameliorates oxidative phosphorylation performance and rescues abeta-induced failure. PLoS One 5, e12359.

[43] Rhein V, Baysang G, Rao S, Meier F, Bonert A, MullerSpahn F, Eckert A (2009) Amyloid-beta leads to impaired cellular respiration, energy production and mitochondrial electron chain complex activities in human neuroblastoma cells. Cell Mol Neurobiol 29, 1063-1071.

[44] Wang X, Su B, Siedlak SL, Moreira PI, Fujioka H, Wang Y, Casadesus G, Zhu X (2008) Amyloid-beta overproduction causes abnormal mitochondrial dynamics via differential modulation of mitochondrial fission/fusion proteins. Proc Natl Acad Sci U S A 105, 19318-19323.

[45] Vander Heiden MG, Cantley LC, Thompson CB (2009) Understanding the Warburg effect: The metabolic requirements of cell proliferation. Science 324, 1029-1033. 